Nos M. M., Postgraduate Student Revenko D. S., Candidate of Economic Sciences, Associate Professor

National Aerospace University "Kharkiv Aviation Institute» Kharkiv, Ukraine

DOI: https://doi.org/10.30525/978-9934-26-028-5-16

\title{
FORMATION OF INDICES FOR ESTIMATING IT PROJECT COST
}

The modern rapid growth of IT industry requires new approaches to managing software development projects, which in its turn encourages specialists to create models and methods for estimating IT project cost. This fact makes the research up-to-date.

Among the main scientists who made a contribution to the development of project management methodology there are the follo- 
wing experts: S. Bushuiev, V. Vartanian, N. Dotsenko, A. Kazarezov, I. Kononenko, K. Koshkin, S. Ryzhkov, M. Fateiev, I. Chumachenko.

The purpose of the research is to form estimation indices in the concept of IT project cost management. The following tasks are set for this work: to designate criteria of IT project cost estimation and form a sequence of stages in IT project cost management.

Project cost management is a set of interrelated coordinated complex tasks which are set for a project manager to provide adherence to the project budget [3; 4]. Specific features of IT projects consists in significant complexity of a project task implementation, a large number of IT specialists engaged in the project and a substantial cost of the project. Therefore IT project cost management is an up-todate contemporary task.

The process of estimating the project cost consists in developing the budget of total expenditures on resources which are necessary to realize an IT project. IT project cost management includes planning of expenditures, budget formation, resources cost control and development of adjusting measures concerning correspondence of these resources to the project budget. Thus, management of an IT project cost change is provided [1].

IT projects can be divided into the following types: IT projects on development and improvement of software, projects on introduction of information systems or infrastructure projects.

Among the main methodologies of IT project management the main four ones should be highlighted: Scrum, Kanban, cascade and iteration methodology. Depending on the requirements for the project results as well as on time and resources limits this or that methodology or their combination can be chosen [2]. Therefore IT project cost indices may be different depending on the methodology and a project type.

The following indices should be highlighted among the main ones:

- total expenditures of the project budget;

- work structure hierarchy;

- contract cost;

- resource norms and their cost; 
- duration of work on each task;

- reserves of cost and time for each task of a project.

According to the corresponding criteria the project cost management can be presented in the form of a sequence of the following processes:

- project cost estimation;

- project budget development;

- accounting and control of the current expenditures as well as auditing of the current cost of the project;

- project implementation analysis according to cost indices, project budget incompliance analysis;

- monitoring of the factors of positive and negative influence on the project cost;

- project changes control, continuous forecast of the project implementation plan according to cost and time criteria;

- making management decisions on the project cost regulation.

At final stages of the project cost management process there are carried out cost analysis and project effectiveness evaluation, settling of claims and conflicts concerning the suggested cost of the project or its separate tasks, preparation of the final financial report on the project, formation of the project cost archive [5].

Cost management is one of the most important functional fields in project management. In the course of the project cost management its manager arranges sequential processes of cost estimation, development of estimate and budget of the project.

A system of IT project cost estimation factors which are the key resulting indices in IT project cost management has been formed during the research. A sequence of stages in IT project cost management has been suggested. The prospects are seen in the development of models and methods of IT project cost management.

\section{References:}

1. Abdikeeva N.M. (2010) Informatsionnyy menedzhment [Information management]. Moscow: INFRA-M, $400 \mathrm{p}$.

2. Rasmusson Dzh. (2012) Gibkoe upravlenie IT-proektami [Flexible IT-project management]. St. Petersburg, 272 p. 
3. Filipkovs'ka L.O., Nos M.M. (2018) Doslidzhennya pidkhodiv do upravlinnya vartistyu innovatsiynykh proektiv [Study of the cost management approaches of innovation projects]. Project Management and Development of Production, vol. 4, no. 68, pp. 5-15.

4. Filipkovs'ka L.O., Nos M.M. (2020) Upravlinnya vartistyu innovatsiynoho proyektu u promysloviy sferi [Cost management of an innovative project in the industrial sphere]. Innovative technologies and scientific solutions for industries, vol. 2, no. 12, pp. 66-74.

5. Tsil'ker B.Ya., Orlov S. (2012) Tekhnologii razrabotki programmnogo obespecheniya [Software development technologies]. St. Petersburg, 608 p. 